総説

\title{
小児における抗真菌薬の投与とその問題点
}

\author{
西 本 勝太郎
}

長崎市民病院皮膚科

Key words : 抗真菌剂 (antifungal drugs), 小児 (pediatric use), 副作用 (side effects)

\section{I 小児における抗真菌薬剤}

抗真菌薬にかぎらず，小児に使用する薬剤については， 一般的に要求されるいくつかの特性，すなわち高い有効 性, 安全性, 経済性, 保存性などに加えて,

1）味, 匂いなどを含めて使用しやすい郕形であるこ と,

2 ) 使用量の調節が可能であること,

3 ) 短い治療期間で効果が現れること,

4 ）より高い安全性と低い副作用率,

5 ）他剂との相互作用の少ないこと, などが求められる.

1）2）に関しては，内服剂については錠剤よりは液 剤，あるいは細粒の方が好ましく，4）に関しては，外 用剤を誤って他部位に使用した場合の刺激性や，全身使 用の薬剤については生長やホルモンへの影響, あるいは 特定の組織への沈着がとくに重視される。

\section{II 小児に対する抗真菌剤とその適応疾患}

抗真菌剂で, 小児用として作られた薬剤はない。外用 凰, 全身用薬剤ともに, 市販されているものはいずれも 成人用としての製剤であり，例えば錠剂などは，1錠中 には成人用としての薬剤量が含まれている.

外用剂については，市販の製品を使用してとくに問題 となることはない.内服用抗真菌剤の使用に際しては成 人量から換算するが，とくに厳密に行う必要はなく, 一 般的な体重比によるもので十分である. 新生児について は，代謝速度を考慮して幾分少な目にする方がよいとさ れる。

またとくに小児に対して使用が制限される薬剤もない が, 抗真菌剤は全身状態の悪化した患者に使用されるこ とが多いため,副作用の発現にはとくに注意を要する。

小児に打いて内服用抗真菌剤が使用されることの多い 真菌症と，その時に選ばれる薬剂としては,

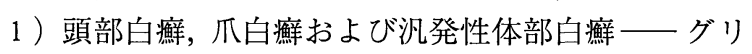
セオフルビン, イトラコナゾール, テルビナフィ

別刷請求先 : 西本勝太郎

=850-8555 長崎市新地町 6-39

長崎市民病院皮膚科

\section{ンなどの内服}

2 ) 慢性皮膚粘膜カンジダ症, 深在性皮膚カンジダ症, カンジダやアスペルギルスなどによる内臓の真菌 症一アムフォテリシン B, イトラコナゾール， フルコナゾール, テルビナフィン

3 ) 爪真菌症一イトラコナゾール，テルビナフィン

などがあるが, 抗細菌性抗菌剤に比して系統拉よび種 類は少ない.これらのほかに特殊なものとして，ヨウ化 カリウムがスポロトリクス症に用いられている. 長年唯 一の, 全身性の抗真菌郕であったアムフォテリシン B は, その副作用のためにとくに小児に対して使用しにくい薬 剤であったが, 抗菌スペクトラムの広さと優れた抗真菌 活性のため，未だに一部で使用されており，とくに最近 リポソーム製剂など新しいdrug delivery systemによる 製品が導入されつつある.

皮膚の表在性真菌症（頭部白癬，爪白癬）については, 従来のグリセオフルビンと, 最近導入された新しいトリ アゾール系やベンジルアミン系の, 各病型に打ける有用 性の比較が問題となる。

\section{III 全身用抗真菌薬の特徴と使用法}

\section{1 ) ヨウ化カリウム (Potassium iodide)}

もっとも古くから経口抗真菌剤としてスポロトリクス 症に使用されている。製剤として粉末および錠剤（50 $\mathrm{mg}$ ). 成人量より換算して使用. 成人に対しては 0.1-0.3 $\mathrm{g} /$ day よりはじめ, 0.5-1.0g/day で 2-3 ケ月使用する.

副作用としてヨード過敏のほか, 胃腸障害や苦味があ るため, 健胃薬やシロップなどとの併用が行われる ${ }^{1)}$. スポロトリクス症に対する有効率は明示されていないが, 新しく登場した内服抗真菌剤よりも有効との感触を持つ 人もある。

\section{2 ) アムフォテリシン B}

もっとも初期に出現し, 抗菌スペクトラムの広さと優 れた抗真菌活性のため, 未だにアスペルギルス症に対す る第 1 選択薬として使用されることもあるが 2), 現在で は新しい抗真菌片が無効の時の第 2 選択とされる場合が 多い.

製品としては，100mg錠，10％シロップ，50mg 注が ある. 抗菌スペクトラムは広く Mucorales, Fusarium 属を 
はじめ，ほとんどの病原真菌をカバーする。

一般的な使用量は, 侵襲性カンジダ症にたいして 0.5 $-0.75 \mathrm{mg} / \mathrm{kg} / \mathrm{day}$ ，この薬剂に対して感受性の低い菌種 Candida krusei, Candida tropicalisなどが原因菌と考えら れる場合には，1.0-1.5mg $/ \mathrm{kg} / \mathrm{day}$ ，侵襲性のアスペルギ ルス症に対しては，1.0-1.5 $(\mathrm{max}) \mathrm{mg} / \mathrm{kg} / \mathrm{day}$ ををゆく り静注する.フルシトシンとの併用は相乗効果を示す. 使用時の発熱や悪寒，腎障害などの副作用のためにとく に小児に対して使用しにくいほか，相互作用としてアミ ノグリコシド，ステロイド，ACTH などが注意を要する.

最近リポソーム製剂など新しい drug delivery system による製品が導入されつつある.

消化管からは殆ど吸収されないため，内服用シロップ はカンジダなどによる消化管の真菌症あるいは真菌の過 剩な増殖を押さえる目的で使用される.

3 ) グリセオフルビン

$125 \mathrm{mg}$ 錠として多数の製品あり. 成人に対し 1 日 3-4 錠が使用される，小児に対しては $15 \mathrm{mg} / \mathrm{kg} / \mathrm{day}$ で換算 して使用する ${ }^{3)}$.

小児投与に対しての適当な剂形がないため，錠剂を成 人量から換算して用いるが，粉末とした場合苦味がある ために用いにくい1).

抗菌スペクトラムは極度に狭く，皮膚糸状菌（白癬菌） にのみ有効であるが，現在でもまだ頭部白癬，汎発性白 癬の第 1 選択薬である. 治療期間は頭部白癬に対しては 3 ケ月，体部白癬に対しては皮疹消褪後さらに 2 週間ぐ らいの追加投与が目安となる.

抗菌作用が静菌的であるため，爪白癬に対する完治率 については新しい薬剤に劣る.

使用禁忌はポルフィリン症，肝障害，過敏症など．慎 重投与として SLE またはその素因のある患者，薬物の相 互作用の点からはバルビッレート投与中の患者があげら れる. 副作用として過敏症, 光線過敏, 消化器障害, SLE 様症状などがあげられるが，光線過敏の出現率は報告に よって差があり頻度は確認されていないが，その他の副 作用も含めて実際の投与に際して問題となることは少な (4). 消化器障害も胃腸症状を除いて頻度は低い5).

\section{4 ) フルシトシン}

製品は $500 \mathrm{mg}$ 錠のみ. 例外的な予防的投与を除き小児 における使用機会は稀. 成人への使用量は消化器，尿路 感染の場合 50- $100 \mathrm{mg} / \mathrm{kg} / \mathrm{day}$. その他の深在性真菌症で は 100-200mg/kg/day. 注意として血液障害．副作用は 汎血球減少, 消化器症状, 光線過敏など.アムフォテリ シン B との併用で相乗効果を期待することもある.

\section{5 ）ミコナゾール}

製品として $100 \mathrm{mg}, 200 \mathrm{mg}$ の注射用があるほかに経口

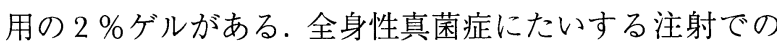
使用量は200-400mg 1日 3-4 回（静注），口腔・食道 カンジダ症に対しては, 経口用剤 $2-4 \mathrm{ml}$ を 1 日 4 回投 与する。

禁忌は過敏症, テルフェナジン, アステミゾール投与 中, 妊娠時など.
相互作用は上記薬のほかにフェニトイン，クマリン製 剂，トリアゾラム，シサプリド，リファンピシン.

副作用としては過敏症, 造血器障害, 精神神経症状, 消化器障害など. 注射薬に含まれるポリオキシエチレン 硬化ヒマシ油による過敏症など.

新しい薬剤の出現によって, 使用される機会は激減し た。

6 ）イトラコナゾール

製品として $50 \mathrm{mg}$ カプセル. 表在性真菌症に対しては 1 日 50-100mg，その他に対しては 100-200mg（最大 200 mg）が使用されるが，外国におけるパルス療法では 1 日 $400 \mathrm{mg}$ （1 週間）が用いられる. 小児に対しては $3-5$ $\mathrm{mg} / \mathrm{kg} / \mathrm{day}^{5)}$ の数字が示されている.

禁忌・相互作用で問題となり易いものとしてテルフェ ナジン，アステミゾール，トリアゾラム，シサプリド， エリスロマイシン，リファンピシンなど。副作用として は過敏症, 消化器障害, 腎障害, 造血器障害, 精神神経 症状など.

広い抗菌スペクトラムを持ち, 副作用の発現頻度も比 較的低いため，小児を含めて安全に使用できる。注意す ベき点はイトラコナゾールが肝内の cytochromeP450を 介する代謝経路で処理されるため，同じく $\mathrm{P} 450$ が関与す る薬剤との間に相互作用を起こしやすい事である。とく に高齢者では必然的に基礎疾患や合併症のために多数の 薬剂を使用する機会が多く, 薬剤間の相互重用が問題と なりやすい.この点に関しては，小児ではそのような機 会の少ないことが，この薬の有用性を高めている. Abel$\mathrm{Rahman}^{6)}$ は小児の頭部白癬 25例に対し $100 \mathrm{mg} /$ day で 4 週間の治療を行い $40 \%$ に有効，8週投与までの症例でと くに問題となる副作用はなかったと報告している.

わが国において，小児への投与は報告数が少ないが, 高瀬 ${ }^{7)}$ は 2 才 (25mg/day) から 8 才 (50-100mg/day) の 頭部白癬 2 例に有効, 副作用無しの結果をえたが, 高橋8) の 2 例のうち 3 才 $(50 \mathrm{mg} / \mathrm{day})$ に 2 週後 GOT, LDH の上昇を見た. ただしこの症例は継続して21日の投与が なされており，4週目にはこれらの值は回復している.

深在性真菌症に対しては高瀬ら9）は 2 例のスポロトリ コーシス（3才，5才）にたいし 50-100 mg/dayを使用 し 9-11 週後全例著効の成績をえた. 他にもいくつか単 独例について同様の成績が見られている，アスペルギル ス症, 黒色真菌感染症に対しては, フルコナゾールより 有用であったとの報告もある。

とくに最近ではコンプライアンスと経済性を高めるた め，また副作用の発現を抑えることを期待して，間欠投 与などが試みられている。

我が国においては比留間10) が18才男子のケルスス秃 瘡に対してイトラコナゾールの週 1-2 回 100mg 13 週の 間欠投与を行い，治癒させた成績を報告している. Gupta 11) は爪真菌症など長期の投与が必要な疾患に対し，20 $\mathrm{kg}$ 以下の小児に対し $5 \mathrm{mg} / \mathrm{kg} /$ day 1 週間投与を月ごと に, 指の病変では 2 パルス, 足で 3 パルスを提唱してい る. 


\section{7 ) フルコナゾール}

製品は $50 \mathrm{mg}, 100 \mathrm{mg}$ のカプセル. 使用量は, 成人に対 してカンジダ症で50-100mgを 1 日 1 回, その他の深在 性真菌症で 100-200（ $\max .400 ） \mathrm{mg}$ となっている.

小児への投与量は生後 4 週以上では, 皮膚粘膜真菌症 で $3 \mathrm{mg} / \mathrm{kg} / \mathrm{day}$, 深在性真菌症 $6 \mathrm{mg} / \mathrm{kg} / \mathrm{day}$, 重篤な真 菌感染症 $12 \mathrm{mg} / \mathrm{kg} / \mathrm{day}$ を 1 日 1 回とし, 生後 $2-4$ 週で は同用量を 2 日に 1 回, 生後 2 週以下では 3 日に 1 回投 与 ${ }^{12)}$, あるいは 1 才以下にたいし $2-5 \mathrm{mg} / \mathrm{kg} / \mathrm{day}$ を投 与する ${ }^{13)}$.

禁忌・相互作用で問題となり易いものとしてテルフェ ナジン, アステミゾール,トリアゾラム, シサプリドな ど.

副作用としては過敏症, Stevens-Johnson 症候群, Toxic epidermal necrolysis, 消化器障害, 腎障害, 造血器障害, 精神神経症状.

抗菌スペクトラムは広く, 適応はカンジダ属, クリプ トコックス属, アスペルギルス属による真菌血症, 呼吸 器 ·消化管 ·尿路感染症, 髄膜炎などとなっており, わ が国では皮膚の表在性真菌症の適応はとれていない.

小児に対する投与は多くの例があり9,13,14)，社内デー 夕でも深在性真菌症に対して，3才児に 100-250mgを 5 ケ月以上，あるいは $9.5 \mathrm{mg} / \mathrm{kg}$ を 162 日以上投与した例が あり，いずれもとくに副作用は認められていない.わが 国ではまだ導入されていないが内服用液剤は小児用とし て賞用される5).

\section{8 ) 塩酸テルビナフィン (Terbinafine hydrochloride)}

製品: $125 \mathrm{mg}$ 錠. 抗菌スペクトラムは広いが適応症は 皮膚糸状菌症, カンジダ属 (爪カンジダ症), スポロト リクス症, フォンセカエア属 (黒色真菌症) など皮膚科 領域が主となっている.

小児への使用量として外国では体重別に, $20 \mathrm{~kg}$ 以下で は $62.5 \mathrm{mg} / \mathrm{day}, 20-40 \mathrm{~kg}$ で $125 \mathrm{mg} / \mathrm{day}, 40 \mathrm{~kg}$ 以上 $250 \mathrm{mg}$

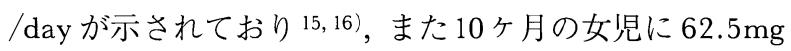
/day，4 週間投与した例もある ${ }^{17)}$. わが国では成人の使 用量が 1 日 $125 \mathrm{mg}$ であり, これに準じて減量可能である.

副作用としては過敏症, Stevens-Johnson症候群, Toxic epidermal necrolysis, 消化器障害, 肝障害, 腎障害, 造 血器障害などがあげられているが, 頻度は低くとくに問 題とはなっていない17-20).

相互作用はシメチジン，リファンピシン.

爪真菌症を含む多くの皮膚科領域の真菌感染症に対し て広く，かつ長期間にわたって使用されており，いずれ も優れた効果と低い副作用率が示されている19).

$$
\text { IV をとめ }
$$

以上述べたように抗真菌剂の小児に対する投与に際し ては他種, 他薬効の薬歳にくらべてとくに問題となる点 はない, 外用剤については成人用剤がそのまま使用可能 である. 内服剂あるいは注射剤についても, 最近市場に 現れたいくつかの薬剤は従来のものにくらべて広い抗菌 スペクトラム, 高い抗菌活性とともに副作用の発現率も
低く使いやすいという点で評価が一致しており，小児へ の使用における安全性は確認されたと考える.

今後の課題としてシロップ剂など, 用量の調節が出来 やすく，内服しやすい小児用製剤の導入があげられよう.

\section{文献}

1）渡辺晋一: 経口抗真菌剤の治療の実際－最近の動向一。 皮膚臨床, 39 : 1925-1930, 1997.

2) Ritter J, Roos N:Special aspects related to invasive fungal infections in children with cancer. Bailliere's Clinical Infections Diseases 2 : 179-204, 1995.

3) Chapel KL, Rasmussen JE: Pediatric dermatology: Advances in therapy. J Am Acad Dermatol 36:

4) Aste N, Pau M, Biggio P: Kerion celsi: a clinical epidemiological study. Mycoses 41 : 169-173, 1998.

5) Elewski BE: Cutaneous mycoses in children. Brit J Dermatol 134 (suppl. 46) : 7-11, 1996.

6) Abel-Rahman SM, Powell DA, Nahata MC: Efficacy of itraconazole in children with Trichophyton tonsurans tinea capitis. J Am Acad Dermatol 38 :443-446, 1998.

7）高瀬孝子：イトラコナゾールによる頭部白痽 6 例の治療 経験. 基礎と臨床 $25:$ 549-555, 1991.

8）高橋泰英, 内藤静夫，中嶋 弘：皮膚真菌症におけるの 臨床使用経験. 基礎と臨床 25 : 497-505, 1991.

9）高瀬孝子,上野賢一: 自験スポロトリコーシス 12 例に対 するイトラコナゾールの治療効果. 基礎と臨床 $25: 563$ 570, 1991.

10）比留間政太郎, 番場圭介, 野口博光, 川田 暁, 石橋 明: 小児のケルスス秃瘡ーフルコナゾール，イトラコナゾー ルの間欠投与が奏効した例. 皮膚病診療 $17: 849-852$, 1995.

11) Gupta K, Sibbald G, Lynde CW, Hull PR, Prussick R, Shear NH, De Doncker P, DanielIII R, Elewski BE : Onychomycosis in children: Prevalence and treatment strategies. Am Acad Dermatol 36 : 395-402, 1997.

12) Brammer $\mathrm{KW}:$ The $\mathrm{XX}$ th International Congress of Pediatrics, Brasil, 1992 (社内資料).

13) Schwarze R, Penk A, Pittrow L:Anwendung von Fluconazol bei Kindern < 1 Jahr: Ubersicht, Mycoses 41 (Suppl, 1) : 61-70, 1998.

14) Driessen M, Ellis JB, Cooper PA, Wainer S, Muwazi F, Hahn D, Gous H, De Villiers FPR : Fluconazole vs. amphotericin B for the treatment of neonatal fungal septicemia: a prospective randomized trial. Pediatr Infect Dis J 15 : 1107-1112, 1996.

15) Solomon BA, Collins R, Sharm R, Silverberg N, Jain AR, Sedgh J, Laude TA : Fluconazole for the treatment of tinea capitis in children. J Am Acad Dermatol 37 : 274-275, 1997.

16) Baudraz-Rosselet F, Monod M, Jaccoud S, Frenk E : Eficacy of terbinafine treatment of tinea capitis in children varies according to the dermatophyte species. Brit J Dermatol 135 : 1011, 1996.

17) Krafchik K, Pelletier $J$ : The use of oral terbinafine (Lamisil) in children. Dermatology $194: 43-44,1997$.

18) Nejjam F, Zagura M, Cabiac MD, Guessous N, Hubert $\mathrm{H}$, Lakhdar $\mathrm{H}$ : Pilot study of terbinafine in children suffering from tinea capitis: Evaluation of efficacy, safety and pharmacokinetics. Brit J Dermatol 132 : 98-105, 1995.

19) Jones TC: Overview of the use of terbinafine (Lamisil) 
in children. Brit J Dermatol 132 : 683-689, 1995.

20) Rosenthal JR : Pediatric fungal infections from head to toe: what's new?. Current Opinion in Pediatrics $6: 435$ $-441,1994$.

\section{Antifungal Drugs for Pediatric Use}

\section{Katsutaro Nishimoto}

Division of Dermatology, Nagasaki Municipal Hospital, Shinchi-machi 6-39, Nagasaki 850-8555, Japan

There are no specialized formulations of antifungal drugs in Japan which are prepared for children. Modification of the therapeutic doses by age groups or by body weight of the patients from the recommended doses for adults as well as special precautions against side effects are needed for pediatric use.

Reports focusing on the side effects of topical and systemic antifungal drugs are reviewed. All the newly introduced systemic drugs, such as fluconazole, itraconazole and terbinafine, have been well tolerated during the treatment of fungal infections of neonates and infants. 